\title{
KECERNAAN PROTEIN DAN ENERGI RANSUM BROILER YANG MENGGUNAKAN TEPUNG MAGGOT (HERMETIA ILLUCENS) SEBAGAI PENGGANTI TEPUNG IKAN
}

\author{
Vanessa Rambet*, J. F. Umboh, Y. L. R. Tulung, Y. H. S. Kowel \\ Fakultas Peternakan Universitas Sam Ratulangi Manado, 95115
}

\begin{abstract}
ABSTRAK
Sebagai pakan, maggot dari black soldier fly (Hermetia Illucens) memiliki kandungan protein dan lemak yang tinggi. Masih sedikit data tentang kecernaan energi dan protein ransum yang mengandung maggot. Penelitian ini dilakukan untuk mengetahui pengaruh penggantian tepung ikan dengan tepung maggot dari black soldier fly (Hermetia Illucens) dalam ransum terhadap kecernaan energi dan protein pada ayam broiler. Dua puluh ekor ayam broiler dengan empat ulangan digunakan dalam penelitian ini dengan menggunakan rancangan acak lengkap (RAL). Ransum penelitian disusun sebagai berikut: R0 $=100 \%$ tepung ikan (15\% dalam ransum) $+0 \%$ tepung Maggot (0\% dalam ransum); R1 $=75 \%$ tepung ikan $(11,25 \%$ dalam ransum) $+25 \%$ tepung Maggot (3,75\% dalam ransum); $\mathrm{R} 2=50 \%$ tepung ikan $(7,5 \%$ dalam ransum $)+50 \%$ tepung Maggot (7,5\% dalam ransum); R3 = $25 \%$ tepung ikan $(3,75 \%$ dalam ransum) $+75 \%$ tepung Maggot (11,25\% dalam ransum); dan $\mathrm{R} 4=0 \%$ tepung ikan $(0 \%$ dalam ransum $)+$ $100 \%$ tepung maggot (15\% dalam ransum). Parameter yang diukur yaitu kecernaan energi dan protein ransum. Kecernaan energi and protein dilakukan berdasarkan metode indikator (lignin) internal.
\end{abstract}

*Korespondensi (corresponding author): Email: vanessa.rambet@yahoo.co.id
Data dihitung berdasarkan Anova sesuai petunjuk rancangan yang digunakan untuk rancangan acak lengkap. Perbedaan yang nyata ditetapkan apabila $\mathrm{P}<0.05$. Hasil penelitian menunjukkan bahwa ternyata kecernaan bahan kering, energi, dan protein pada perlakuan $\mathrm{R} 1$ meningkat secara nyata $(\mathrm{P}<0.05)$ dibanding perlakuan R0, R2, R3, dan $\mathrm{R} 4$. Tidak ada perbedaan yang nyata ( $\mathrm{P}$ $>0.05)$ ditunjukkan antara perlakuan R0, R2, R3, dan R4. Dapat disimpulkan tepung maggot paling baik digunakan sampai dengan level $25 \%$ menggantikan tepung ikan atau $11,25 \%$ dalam ransum. Namun, hasil penelitian ini mengindikasikan bahwa tepung maggot dapat digunakan sampai dengan $100 \%$ menggantikan tepung ikan dalam ransum ayam broiler tanpa adanya efek negatif terhadap kecernaan bahan kering, energi, dan protein.

Kata Kunci: Tepung ikan, tepung maggot (Hermetia Illucens), kecernaan energi dan protein.

\section{ABSTRACT}

ENERGY AND PROTEIN DIGESTIBILITY OF BROILER CHICKEN CONSUMING MAGGOT (HERMETIA ILLUCENS) MEAL SUBSTITUTING FISH MEAL IN THE DIETS. As an animal feed, maggot from black soldier fly (Hermetia Illucens) has high protein and fat content. Yet, little is known 
about the digestibility of energy and protein in the diet containing maggot. The present study was conducted to determine the effect of substitution of fish meal with maggot meal in the diets on energy and protein digestibility of broiler chicken. Twenty chicks were assingned to each dietary treatment which was replicated four times in a completely randomized design (CRD). Tretaments were formulated as follow: $\mathrm{R} 0=100 \%$ fish meal $(15 \%$ in the diet $)$ $+0 \%$ maggot meal ( $0 \%$ in the diet); R1 $=75 \%$ fish meal $(11,25 \%$ in the diet $)+$ $25 \%$ maggot meal $(3.75 \%$ in the diet); $\mathrm{R} 2=50 \%$ fish meal $(7.5 \%$ in the diet $)+$ $50 \%$ maggot meal $(7.5 \%$ in the diet); $\mathrm{R} 3=25 \%$ fish meal $(3.75 \%$ in the diet) $+75 \%$ maggot meal $(11.25 \%$ in the diet); and R4 $=0 \%$ fish meal $(0 \%$ in the diet $)+100 \%$ maggot meal $(15 \%$ in the diet). Parameters measured were energy and protein digestibility. Energy and protein digestibility were calculated using the indicator (internal lignin) method. All data was submitted to the ANOVA procedure for completely randomized design. Differences were considered significantat $(\mathrm{P}<0.05)$. The results showed that dry matter, energy, and protein digestibility were increased significantly $(\mathrm{P}<0.05)$ compared to R0, R2, R3, and R4. No significant difference $(\mathrm{P}>0.05)$ were found among R0, R2, R3, and R4. It can be concluded that the maggot flour is best used to the level of $25 \%$ replacing fish meal or $11.25 \%$ in the ration. However, the result of this study indicate that maggot flour can be used up to $100 \%$ replace fish meal in broiler chicken rations without any negative effect on digestibility of dry matter, energy, and protein.

Keywords: Fish meal, maggot (Hermetia Illucens) meal, energy and protein digestibility.

\section{PENDAHULUAN}

Penyediaan bahan pakan sering mengalami kendala akibat ketersediaannya yang berfluktuasi tergantung faktor cuaca dan kemampuan produksi petani dan nelayan. Untuk mencukupi kebutuhan, bahan pakan harus didatangkan dari luar daerah ataupun luar negeri dengan harga yang lebih mahal sehingga meningkatkan biaya produksi. Tepung ikan merupakan salah satu bahan pakan sumber protein dalam ransum unggas. Kenyataan yang ada dan sering dihadapi peternak bahwa tepung ikan, kualitasnya tidak menentu karena diolah dari berbagai sumber, dan ketersediaannya ada kalanya terbatas, sehingga mempengaruhi kualitas dan harga ransum. Upaya untuk mengatasi haltersebut salah satunya dengan mencari bahan ransum alternatif yang kualitasnya hampir sama dengan tepung ikan (Murtidjo, 2001). Bahan pakan yang tersedia dan belum sepenuhnya dimanfaatkan dalam ransum, khususnya ransum unggas yaitu Maggot dari lalat black soldier fly (Hermetia illucens) dapat dijadikan suatu pilihan untuk penyediaan pakan sumber protein. 
Keunggulan dari maggot sebagai bahan pakan yaitu kandungan protein dan lemaknya yang tinggi. Maggot atau belatung dari lalat black soldier fly (Hermetia illucens) mengandung: protein kasar $\pm 50 \%$ dan lemak $\pm 25 \%$ (Bondari dan Shepard, 1987). Hasil penelitian dari Loka Riset Kementerian Kelautan dan Perikanan menyebutkan bahwa belatung memiliki kadar protein yang hampir sama atau mendekati tepung ikan, yaitu sekitar 4050\%. Maggot bisa menggantikan tepung ikan dalam produksi ayam broiler dan mempengaruhi secara positif pertumbuhan berat dan kecernaan ternak ayam (Téguia et al, 2002).

Tingginya kandungan protein pada belatung dari lalat black soldier fly (Hermetia illucens) belum menjamin tingginya tingkat ketersediaan protein di dalamnya. Tinggi rendahnya tingkat ketersediaan (availabilitas) protein dapat dilihat dari nilai kecernaannya. Kecernaan suatu bahan pakan merupakan pencerminan dari tinggi rendahnya nilai manfaat dari bahan pakan tersebut. Nilai kecernaan yang rendah, menunjukannilai manfaat yang rendah pula, sebaliknya apabila kecernaannya tinggi maka nilai manfaatnya juga tinggi. Upaya penggantian tepung ikan dengan dengan tepung maggot akan lebih memberikan nilai guna apabila diketahui nilai kecernaannya. Kecernaan ini perlu diketahui dalam upaya untuk mencapai efesiensi penggunaan pakan dalam ransum yang diberikan. Hal ini tidak bisa terlepas dari kandungan energi dan protein didalam ransum yang sangat mempengaruhi konsumsi pakan.

Berdasarkan uraian di atas, penelitian ini dirancang untuk melihat sejauh mana penggantian tepung ikan dengan tepung maggot dalam ransum terhadap kecernaan bahan kering, energi, dan protein pada broiler finisher.

\section{MATERI DAN METODE PENELITIAN}

\section{Ternak Percobaan}

Penelitian ini menggunakan 20 ekor ayam pedaging strain CP 707 fase finisher berumur 5-6 minggu dengan berat badan berkisar antara 1.092 1.320 gram. Kandang yang digunakan dalam penelitian ini yaitu kandang battery yang berukuran $40 \times 30 \times 30$ $\mathrm{cm}$. Setiap unit kandang ditempati oleh 1 ekor ternak ayam.Peralatan yang digunakan dalam penelitian ini yaitu: wadah pencampur ransum, timbangan analytical / digital untuk bahan pakan 
Tabel 1. Komposisi Zat-zat Makanan Penyusun Ransum $\left.{ }^{*}\right)$

\begin{tabular}{lcccccc}
\hline \multirow{2}{*}{ Bahan Pakan } & \multicolumn{6}{c}{ Kandungan zat-zat makanan } \\
\cline { 2 - 7 } & Protein & $\begin{array}{l}\text { Serat } \\
\text { Kasar }\end{array}$ & Lemak & Ca & P & $\begin{array}{c}\text { EM } \\
(\mathrm{kkal} / \mathrm{kg})\end{array}$ \\
\hline Jagung Kuning & 9,42 & 2,15 & 5,17 & 0,22 & 0,60 & 3,182 \\
Dedak halus & 13,2 & 6,35 & 6.07 & 0,19 & 0,73 & 2,878 \\
Bungkil kelapa & 24,7 & 15,02 & 9,36 & 0,11 & 0,47 & 3,498 \\
Tepung ikan & 55,0 & 0,17 & 12,1 & 5,1 & 2,8 & 3,468 \\
Tepung Maggot & 48,0 & 1.29 & 33,0 & 0,39 & 0,15 & 4,561 \\
Tepung Kedelai & 49,0 & 2,27 & 8,26 & 0,32 & 0,58 & 3,910 \\
Top Mix & - & - & - & 5.38 & 1.44 & - \\
\hline *)
\end{tabular}

${ }^{*}$ Hasil analisis laboratorium Universitas Padjajaran, Bandung. 2015

Tabel 2. Susunan Bahan Pakan dan Kandungan Zat-zat Makanan Ransum Fase Pemeliharaan Akhir (Finisher)

\begin{tabular}{|c|c|c|c|c|c|}
\hline \multirow{3}{*}{ Bahan Pakan } & \multicolumn{5}{|c|}{ Perlakuan } \\
\hline & R0 & R1 & R2 & R3 & R4 \\
\hline & \multicolumn{5}{|c|}{ Proporsi $(\%)$} \\
\hline Jagung kuning & 55 & 55 & 55 & 55 & 55 \\
\hline Dedak halus & 21 & 21 & 21 & 21 & 21 \\
\hline Bungkil kelapa & 3 & 3 & 3 & 3 & 3 \\
\hline Tepung kedele & 5 & 5 & 5 & 5 & 5 \\
\hline Tepung ikan & 15,0 & 11.25 & 7.5 & 3.75 & - \\
\hline Tepung maggot & - & 3.75 & 7.5 & 11.25 & 15,0 \\
\hline Mineral (Top mix) & 1 & 1 & 1 & 1 & 1 \\
\hline Total & 100 & 100 & 100 & 100 & 100 \\
\hline \multicolumn{6}{|l|}{ Komposisi nutrien $^{\#)}$} \\
\hline Protein & 19.53 & 19.23 & 18.93 & 18,64 & 18.34 \\
\hline Lemak & 6.62 & 7.41 & 8.19 & 8.98 & 9.76 \\
\hline Serat kasar & 3.10 & 3.18 & 3.18 & 3.23 & 3.27 \\
\hline $\mathrm{Ca}$ & 1.00 & 0,92 & 0,86 & 0,74 & 0,69 \\
\hline $\mathrm{P}$ & 0.96 & 0,86 & 0,76 & 0,66 & 0,56 \\
\hline $\mathrm{ME}(\mathrm{Kkal} / \mathrm{kg})$ & 3175,0 & 3216,0 & 3257,0 & 3298,0 & 3319,0 \\
\hline
\end{tabular}

\#) Dihitung berdasarkan hasil analisis dan perhitungan data Tabel 1.

dan ternak ayam, serta alat penampung ransum. Bahan-bahan pakan yang digunakan sebagai penyusun ransum yaitu jagung kuning, dedak halus, bungkil kelapa, tepung kedelai, tepung ikan dan tepung Maggot yang saling menggantikan dan top mix sebagai makanan pelengkap. Komposisi zat-zat makanan pakan penyusun ransum tercantum pada Tabel 1, dan Tabel 2 menyajikan susunan pakan ransum percobaan dan kandungan nutrisinya. 
Ransum perlakuan yang diberikan diformulasi sebagai berikut:

$\mathrm{R} 0=100 \%$ tepung ikan $(15 \%$ dalam ransum) $+0 \%$ tepung Maggot (0\% dalam ransum);

$\mathrm{R} 1=75 \%$ tepung ikan $(11,25 \%$ dalam ransum) $+25 \%$ tepung Maggot (3,75\% dalam ransum);

$\mathrm{R} 2=50 \%$ tepung ikan $(7,5 \%$ dalam ransum) $+50 \%$ tepung Maggot (7,5\% dalam ransum);

$\mathrm{R} 3=25 \%$ tepung ikan $(3,75 \%$ dalam ransum) $+75 \%$ tepung Maggot (11,25\% dalam ransum); dan

$\mathrm{R} 4=0 \%$ tepung ikan $(0 \%$ dalam ransum) $+100 \%$ tepung Maggot (15\% dalam ransum)

\section{Persiapan Media dan Wadah}

\section{Budidaya}

Kegiatan budidaya maggot dilakukan dengan membuat media tumbuh maggot yaitu dengan menggunakan $1 \mathrm{~kg}$ bungkil kelapa. Bahan media dicampurkan dengan satu liter air, air ditambahkan secara perlahan, agar media tidak terlalu basah. Media diaduk secara merata dan digemburkan. Setelah itu media yang telah siap, diletakkan pada wadah yang telah disiapkan sebagai tempat peletakkan media agar lalat Black soldier bertelur pada media tersebut, setelah itu media ditutup dengan trash bag hitam. Media dibiarkan selama sepuluh hari dan siap dipanen.

\section{Metode Penelitian}

\section{Rancangan Percobaan}

Penelitian ini menggunakan metode eksperimen dengan rancangan acak lengkap (completely randomized design) yang terdiri dari lima perlakuan dan empat ulangan. Data hasil penelitian ditabulasi dan dianalisis keragamannya sesuai rancangan yang digunakan. Untuk perlakuan yang uji statistiknya berbeda nyata $(\mathrm{P}<0,05)$ analisis dilanjutkan dengan Tukey Test sesuai petunjuk Steel and Torrie (1991).

\section{Tatalaksana Percobaan}

Kandang dibersihkan dengan baik terlebih dahulu sebelumayam percobaan dimasukkan ke dalamnya.Tempat makanan dan air minum diletakkan secara teratur di tiap unit kandang.Ternak percobaan selanjutnya ditempatkan ke dalam 20 unit kandang, masing-masing unit diisi 1 ekor ayam broiler.Mulai umur 3 minggu sampai dengan selesai penelitian, ternak percobaan diberikan ransum fase finisher sesuai dengan perlakuan masing-masing (Tabel 2). 
Teknik pengumpulan sampel feses yang digunakan dalam penelitian ini yaitu dengan metode ileal menggunakan indikator (lignin) (Kim, 2010). Metode ini diamati dengan mempuasakan ayamselama 24 jam untuk mengeluarkan sisa pakan dari saluran pencernaan. Setelah itu ayam diberi ransum perlakuan yang telah disediakan dengan cara force feeding. Force feeding dilakukan dengan memasukkan makanan menggunakan disposible yang dimasukkan langsung ke dalam tembolok. Empat jam kemudian ayam dipotong karena pakan yang diberikan sudah bisa terserap di dalam tubuh ayam. Kemudian usus besar (sekum dan kolon) dikeluarkan untuk mendapatkan sampel feses. Sampel dikeluarkan dari usus besar, dikeringkan, digiling, dan seterusnya dianalisis.

Kecernaan protein ransum dihitung dengan menggunakan rumus sebagai berikut:

Kecernaan protein $(\%)=$ $\frac{(P \text { ransum } / L \text { ransum })-(P \text { digesta } / L \text { digesta })}{P \text { ransum } / L \text { ransum }}$ x 100

di mana:

$\mathrm{P}$ ransum, $\mathrm{P}$ digesta $=$ protein dalam ransum atau digesta
$\mathrm{L}$ ransum, $\mathrm{L}$ digesta $=$ lignin dalam ransum atau digesta

Data dianalisis sesuai prosedur dan petunjuk rancangan yang digunakan.

\section{Parameter yang diukur}

Parameter yang diukur dalam penelitian ini yaitu sebagai berikut:

1. Kecernaan bahan kering ransum

2. Kecernaan energi ransum

3. Kecernaan protein ransum

\section{HASIL DAN PEMBAHASAN}

\section{Pengaruh Perlakuan Terhadap Kecernaan Bahan Kering, Energi, dan Protein Pada Ayam Broiler}

Data kecernaan bahan kering, energi, dan protein dalam penelitian ini dapat dilihat pada Tabel 3.

\section{Kecernaan Bahan Kering}

Kecernaan bahan kering dalam penelitian ini berkisar antara 57,96 $60,42 \%$. Angka kecernaan bahan kering ini masih berada pada kisaran kecernaan bahan kering ayam broiler sebgaimana rekomendasi Blair et al. (1990), dimana kecernaan bahan kering broiler fase finisher berkisar pada angka $50-80 \%$. 
Tabel 3. Data Kecernaan Bahan Kering, Energi, dan Protein

\begin{tabular}{lccccc}
\hline \multirow{2}{*}{ Kecernaan } & \multicolumn{5}{c}{ Perlakuan } \\
\cline { 2 - 6 } & R0 & R1 & R2 & R3 & R4 \\
\hline Bahan Kering (\%) & $58,82^{\mathrm{b}}$ & $60,42^{\mathrm{a}}$ & $58,46^{\mathrm{b}}$ & $58,27^{\mathrm{b}}$ & $57,96^{\mathrm{b}}$ \\
Energi (\%) & $62,03^{\mathrm{b}}$ & $64,77^{\mathrm{a}}$ & $64,37^{\mathrm{a}}$ & $64,60^{\mathrm{a}}$ & $64,72^{\mathrm{a}}$ \\
Protein (\%) & $65,34^{\mathrm{b}}$ & $75,32^{\mathrm{a}}$ & $65,80^{\mathrm{b}}$ & $67,16^{\mathrm{b}}$ & $64,59^{\mathrm{b}}$ \\
\hline
\end{tabular}

Keterangan:Nilai pada baris yang sama dengan superscript yang berbeda menunjukkan perbedaan yang nyata $(\mathrm{P}<0,05)$

Kecernaan bahan kering ransum tertinggi dalam penelitian ini yaitu pada perlakuan R1 (penggantian 25\% tepung ikan dengan tepung maggot atau 3,75\% dalam ransum), sekitar 60,42\%. Lebih tingginya kecernaan bahan kering dan protein pada perlakuan R1 dibanding perlakuan lainnya diduga disebabkan oleh lebih tingginya konsumsi makanan pada perlakuan tersebut dibanding perlakuan lainnya.

Banyaknya kandungan bahan kering yang dicerna berhubungan dengan banyaknya kandungan nutrien yang terserap. Tillman dkk, (1998) mengemukakan bahwa bahan kering yang diekskresikan dalam feses merupakan zat-zat makanan yang tidak diserap tubuh.

\section{Kecernaan Protein}

Kecernaan protein dalam penelitian ini berkisar antara 64,59$75,32 \%$. Angka kecernaan protein ini masih berada pada kisaran kecernaan protein broiler di daerah tropis yang berkisar $60-85 \%$ (Blair, et al., 1990). Hal ini juga sesuai dengan Monica (2012) yang melaporkan hasil penelitian penggunaan Maggot menggantikan tepung ikan dalam ransum ayam broiler dan mendapatkan angka kecernaan protein rata-rata sekitar $73,47 \%$.

Kecernaan protein ransum tertinggi dalam penelitian ini yaitu pada perlakuan R1 (penggantian 25\% tepung ikan dengan tepung maggot atau 3,75\% dalam ransum) sekitar 75,32\%.

Kecernaan protein ransum mengikuti pola kecernaan bahan kering ransum dalam penelitian ini, dimana perlakuan R1 menunjukkan angka kecernaan yang nyata $(\mathrm{P}<0,05)$ lebih tinggi dibanding perlakuan lainnya. Nilai kecernaan protein berkaitan erat dengan kecernaan bahan kering ransum, dimana nilai kecernaan protein berbanding lurus dengan kecernaan bahan kering ransum atau sebaliknya. 
Faktor yang mempengaruhi jumlah kebutuhan protein pada ternak ayam yaitu: tingkat protein, temperatur atau suhu lingkungan, usia ternak ayam, kandungan asam amino, dan daya cerna (Sklan dan Hurtwitz, 1980). Guna mencapai daya cerna protein yang optimal, nilai nutien dari protein harus disesuaikan dengan kebutuhan ayam itu sendiri.

\section{Kecernaan Energi}

Kecernaan energi ransum dalam penelitian ini berkisar antara 62,03 64,77\%. Angka kecernaan energi ini masih berada pada kisaran kecernaan energi ayam broiler didaerah tropis, yaitu berkisar pada angka $60-85 \%$ (Blair et al., 1990). Monica (2012) melaporkan hasil penelitian penggunaan maggot menggantikan tepung ikan dalam ransum ayam broiler, dimana kecernaan energi rata-rata sekitar $75,17 \%$. Kecernaan energi ransum tertinggi dalam penelitian ini yaitu pada perlakuan R1 (penggantian 25\% tepung ikan dengan tepung maggot atau 3,75\% dalam ransum), sekitar $64,77 \%$ dan terendah yaitu pada perlakuan R0 (penggantian $0 \%$ tepung ikan dengan tepung maggot atau 0\% dalam ransum). Lebih tingginya kecernaan energi pada perlakuan R1 dibanding perlakuan R0 diduga disebabkan oleh lebih tingginya konsumsi makanan pada perlakuan tersebut.

Banyaknya kandungan bahan kering dan energi yang dicerna berhubungan dengan banyaknya kandungan nutrien yang terserap. Nilai kecernaan energi berkaitan erat dengan kecernaan bahan kering ransum dan konsumsi makanan, dimana nilai kecernaan energi berbanding lurus dengan kecernaan bahan kering ransum dan konsumsi ransum atau sebaliknya.

Informasi dan data penelitian tentang metabolizable energy (ME) maggot pada ternak ayam broiler masih terbatas. Kandungan energi dan kecernaannya sangat tergantung pada kandungan lemak dan serat kasar dari ransum (Zuidhof et al., 2003)._Tepung maggot telah digunakan dalam ransum ayam broiler sebagai pengganti sumbersumber pakan konvensional, terutama tepung ikan. Kebanyakan penelitian mengindikasikan bahwa penggantian sebagian atau bahkan keseluruhan tepung ikan memungkinkan, namun penggunaan optimal umumnya kurang dari $10 \%$ dalam ransum yang diduga disebabkan oleh menurunnya palatabilitas karena warna hitam 
dari tepung maggot kurang menarik dan tidak disukai ternak ayam (Atteh et al., 1993; Bamgbose, 1999).

\section{KESIMPULAN}

Tepung maggot paling baik digunakan sampai dengan level $25 \%$ menggantikan tepung ikan atau 11,25\% dalam ransum. Namun, hasil penelitian ini mengindikasikan bahwa tepung maggot dapat digunakan sampai dengan $100 \%$ menggantikan tepung ikan dalam ransum ayam broiler tanpa adanya efek negatif terhadap kecernaan bahan kering, energi, dan protein.

\section{DAFTAR PUSTAKA}

Atteh, J. O. ; Ologbenla, F. D., 1993. Replacement of fish meal with maggots in broiler diets: effects on performance and nutrient retention. Nigerian J. Anim. Prod. 20: 44-49.

Bamgbose, A. M, 1999. Utilization of maggot - meal in cockerel diets. Hal. 69 (12).

Bondari K. and D.C. Sheppard. 1987. Soldier fly, Hermetia illucens L., larvae as feed for channel catfish, Ictalurus punctatus (Rafinesque), and blue tilapia, Oreochromis aureus (Steindachner). Aquaculture and Fisheries Management. 18: 209220.

Blair, G. J,Ensiminger, M. E., dan W. W. Heinemman. 1990. Poultry Meat Feed and Nutrition. $2^{\text {nd }} \mathrm{Ed}$
The Ensminger Publishing Company, California.

Kim, E.J. 2010. Amino Acid Digestibility Of Various Feedstuffs Using Different Methods. Dissertation. Doctor of Philosophy in Animal Sciences in the Graduate College of the University of Illinois at Urbana-Champaign, Illinois.

Monica, S. 2012. Pengaruh pemberian tepung Maggot Black Soldier Fly (Hermetia illucens) yang dibiakkan di berbagai media tumbuh terhadap kecernaan bahan kering dan protein kasar pada ayam broiler. J. of Aquaculture and Fish Health. 1(2): 31-36.

Murtidjo B. A. 2001. Pedoman Meramu Pakan Ikan. Kanisius. Yogyakarta

Sklan, D dan S. Hurtwitz, 1980. Protein digestion and absorption in young chick and turkey, J. Nutrition. 10: 134-142.

Steel R.G.D and J.H. Torrie. 1991. Prinsip dan Prosedur Statistika: Suatu Pendekatan Biometrik, Edisi Kedua, P.T. Gramedia Pustaka Utama. Jakarta.

Téguia, A., M. Mpoame, J.A. Okourou Mba. 2002. The production performance of broiler birds as affected by the replacement of fish meal by maggot meal in the starter and finisher diets. Tropicultura. 20 (4): 187-192

Tillman, A. D., H. Hartadi, S. Reksohadiprodjo, S.P. Kusumo dan S. Lebdosoekojo. 1998. Ilmu Makanan Ternak Dasar. 
Gajah Mada University Press. Yogyakarta.

Zuidhof, M. J., C.L. Molnar, F.M. Morley, T.L. Wray, F.E. Robinson, B.A. Khan, L. AlAni, L.A. Goonewardene. 2003. Nutritive value of house fly (Musca domestica) larvae as a feed supplement for turkey poults. Anim. Feed Sci. Technol. 105 (1-4): 225-230. 